\title{
Pengaruh Kompetensi Pegawai, Tingkat Pemanfaatan Teknologi Informasi, dan Efektivitas Sistem Pengendalian Intern Terhadap Penyajian Laporan Keuangan Rumah Sakit TNI AD Di Kesdam XIV/Hasanuddin
}

\section{YOHANES R.H. WIBOWO', HERMAN KARAMOY², LINTJE KALANGI ${ }^{3}$}

\author{
1,2,3 Progam Magister Akuntansi, Fakultas Ekonomi dan Bisnis Universitas Sam Ratulangi \\ Email: restucku07@gmail.com ${ }^{1}$, hermankaramoy@yahoo.com², lintje_kalangi@yahoo.com
}

\begin{abstract}
The presentation of financial statements reflected by opinion of intern auditor (Itdam) and external auditor (BPK). Audit result show there are still many army hospitals which have not yet attained WTP opinion. The variables in this study consist of independent variables: employee competence $\left(X_{1}\right)$, information technology $\left(X_{2}\right)$, and internal control system $\left(X_{3}\right)$. On the other hand, the dependent variable is the presentation of financial statement $(Y)$. This is a quantitative research using non probability sampling with census sampling method. The value of the coefficient of determination shows that employee competence, information technology, and internal control system simultaneously contribute to the presentation of financial statement. Partially test results show that information technology and internal control system influence significantly the quality of financial statement. Employee competence does not influence significantly the presentation of financial statement.
\end{abstract}

Keywords: Presentation of Financial Statement, Employee Competence, Information Technology, and Internal Control System.

\begin{abstract}
Abstrak. Penyajian laporan keuangan rumah sakit TNI AD tercermin dari opini auditor internal (Itdam) maupun eksternal (BPK) atas laporan keuangan rumah sakit TNI AD. Hasil audit menunjukkan masih banyak rumah sakit TNI AD yang belum mendapatkan opini WTP. Variabel dalam penelitian ini sebagai variabel independen adalah kompetensi pegawai $\left(\mathrm{X}_{1}\right)$, tingkat pemanfaatan teknologi informasi $\left(\mathrm{X}_{2}\right)$, dan efektifitas sistem pengendalian intern $\left(\mathrm{X}_{3}\right)$, sedangkan variabel dependen adalah penyajian laporan keuangan $(\mathrm{Y})$. Jenis penelitian ini adalah kuantitatif dengan menggunakan metode linier berganda, dan sampel diambil dengan teknik non probability sampling menggunakan sampling jenuh/sensus pada pengelola keuangan rumah sakit TNI AD di Kesdam XIV/Hasanuddin. Nilai koefisien determinasi menunjukan bahwa kompetensi pegawai, pemanfaatan teknologi informasi dan efektifitas sistem pengendalian intern bersama-sama berkontribusi terhadap penyajian laporan keuangan rumah sakit TNI AD di Kesdam XIV/Hasanuddin. Hasil pengujian secara parsial menunjukkan bahwa pemanfaatan teknologi informasi dan efektifitas sistem pengendalian intern memiliki pengaruh signifikan terhadap penyajian laporan keuangan, sedangkan kompetensi pegawai tidak memiliki pengaruh signifikan terhadap penyajian laporan keuangan.
\end{abstract}

Kata kunci: Penyajian Laporan Keuangan, Kompetensi Pegawai, Pemanfaatan Teknologi Informasi dan Efektifitas Sistem Pengendalian Intern.

\section{Pendahuluan.}

Akuntansi sektor publik merupakan salah satu bidang ilmu yang perkembangannya sangat pesat dalam beberapa tahun terakhir. Tuntutan akuntabilitas dan transparansi yang dihadapi oleh organisasiorganisasi sektor publik terkait penggunaan dana masyarakat menjadikan bidang ilmu ini semakin dibutuhkan. Salah satu contoh organisasi sektor publik adalah rumah sakit. Rumah sakit berdasarkan kepemilikannya dibedakan menjadi rumah sakit pemerintah, rumah sakit berbentuk badan layanan umum, dan rumah sakit swasta. Rumah sakit TNI AD merupakan rumah sakit milik pemerintah yang dipisahkan, karena rumah sakit TNI AD merupakan bagian dari TNI AD. Keadaan rumah sakit TNI AD sangat bergantung pada kondisi keuangan TNI AD yang menjadi induknya.

Penyajian laporan keuangan rumah sakit TNI AD yang valid dan tepat merupakan suatu hal yang menarik untuk dikaji lebih lanjut. Rumah sakit TNI AD sebagai lembaga milik pemerintah yang mengelola 
penerimaan negara bukan pajak dari hasil pelayanan kesehatan atas pemanfaatan kapasitas lebih rumah sakit. Berdasarkan undang undang nomor 1 tahun 2004 tentang perbendaharaan negara pasal 51, kepala satuan kerja selaku pengguna anggaran harus menyelenggarakan akuntansi atas transaksi keuangan, aset, utang, dan ekuitas dana, termasuk transaksi pendapatan dan belanja, yang berada dalam tanggungjawabnya. Hal ini berarti bahwa setiap kepala rumah sakit TNI AD harus menyajikan laporan keuangan unit kerjanya secara valid dan tepat. Dalam pasal 56 UU nomor 1 tahun 2004 menyebutkan bahwa laporan keuangan yang harus dibuat oleh setiap unit kerja adalah laporan realisasi anggaran, neraca, dan catatan atas laporan keuangan, sedangkan yang menyusun laporan arus kas adalah bendahara rumah sakit selaku bendahara umum sesuai dengan Peraturan Menteri Pertahanan RI Nomor 30 tahun 2008. Melalui Peraturan Pemerintah Nomor 71 Tahun 2010 tentang standar akuntansi pemerintah menyatakan basis akuntansi yang digunakan dalam laporan keuangan pemerintah adalah basis akrual.

Penelitian ini penting untuk dilaksanakan karena salah satu faktor penyebab penilaian laporan keuangan Kementrian Pertahanan oleh BPK RI untuk tahun 2017 WDP (Wajar Dengan Pengecualian) adalah penyajian laporan keuangan rumah sakit TNI yang belum valid dan tepat. Laporan keuangan yang valid dan tepat yaitu bebas dari pengertian yang menyesatkan dan kesalahan material, menyajikan setiap fakta secara jujur, dapat diverifikasi, serta tepat waktu. Penelitian tentang faktor - faktor : (1) kompetensi pegawai; (2) tingkat pemanfaatan teknologi informasi; dan (3) efektivitas pengendalian intern dilakukan untuk menguji dan membuktikan secara empiris pengaruhnya terhadap penyajian laporan keuangan rumah sakit TNI, sehingga dapat menjadi masukan dan saran kepada Komando Atas dalam menentukan keputusan dan kebijakan dalam mengelola rumah sakit TNI guna mendukung mewujudkan laporan keuangan Kemhan yang WTP (Wajar Tanpa Pengecualian).

Berdasarkan pemaparan masalah yang telah diuraikan sebelumnya, maka penelitian ini dilakukan dengan tujuan sebagai berikut:

1. Untuk menguji dan membuktikan secara empiris bahwa kompetensi pegawai berpengaruh terhadap penyajian laporan keuangan rumah sakit TNI AD di Kesdam XIV/Hasanuddin.

2. Untuk menguji dan membuktikan secara empiris bahwa tingkat pemanfaatan teknologi informasi berpengaruh terhadap penyajian laporan keuangan rumah sakit TNI AD di Kesdam XIV/Hasanuddin.

3. Untuk menguji dan membuktikan secara empiris bahwa efektivitas sistem pengendalian intern berpengaruh terhadap penyajian laporan keuangan rumah sakit TNI AD di Kesdam XIV/Hassanuddin.

Terdapat beberapa penelitian di bidang pengaruh kompetensi peagawai, tingkat pemanfaatan teknologi informasi, dan efektivitas sistem pengendalian intern terhadap penyajian laporan keuangan. Zuliarti (2012) dalam pengaruh kapasitas pegawai, pemanfaatan teknologi informasi, dan pengendalian intern akuntansi terhadap nilai informasi pelaporan keuangan pemerintah daerah: Studi Pada Pemerintah Kabupaten Kudus, menyatakan kapasitas pegawai, pemanfaatan teknologi informasi, dan pengendalian intern akuntansi berpengaruh positif nilai informasi pelaporan keuangan pemerintah daerah. Sukirman, Havid Sularso, Erly Setyowati Nugraheni (2012) dalam faktor-faktor yang mempengaruhi keterandalan dan ketepatwaktuan pelaporan keuangan dengan pengendalian intern akuntansi sebagai variabel pemoderasi (Studi empiris pada pemerintah daerah kabupaten Banyumas) menyatakan kapasitas pegawai, pemanfaatan teknologi informasi, dan pengendalian intern akuntansi berpengaruh positif terhadap keterandalan dan ketepatwaktuan pelaporan keuangan pemerintah daerah. Nuryanto dan Afiah (2013) dalam the impact of apparatus competence, information technology utilization, and quality (Study on local government of Jakarta Province-Indonesia) menyatakan kompetensi aparatur, pemanfaatan teknologi informasi, dan pengendalian internal berpengaruh terhadap penyajian pelaporan keuangan. Jessy D.L. Warongan, Gagaring Pagalung, Paulus Uppun, Abdul Hamid Habbe (2014) dalam the effect of effectiveness mediation of internal control system on competency of human resources and audit opinion in previous year toward quality of finacial statement menyatakan kompetensi pegawai dan internal control berpengaruh positif terhadap penyajian laporan keuangan. 


\section{Gambar 1. \\ Kerangka Konseptual}

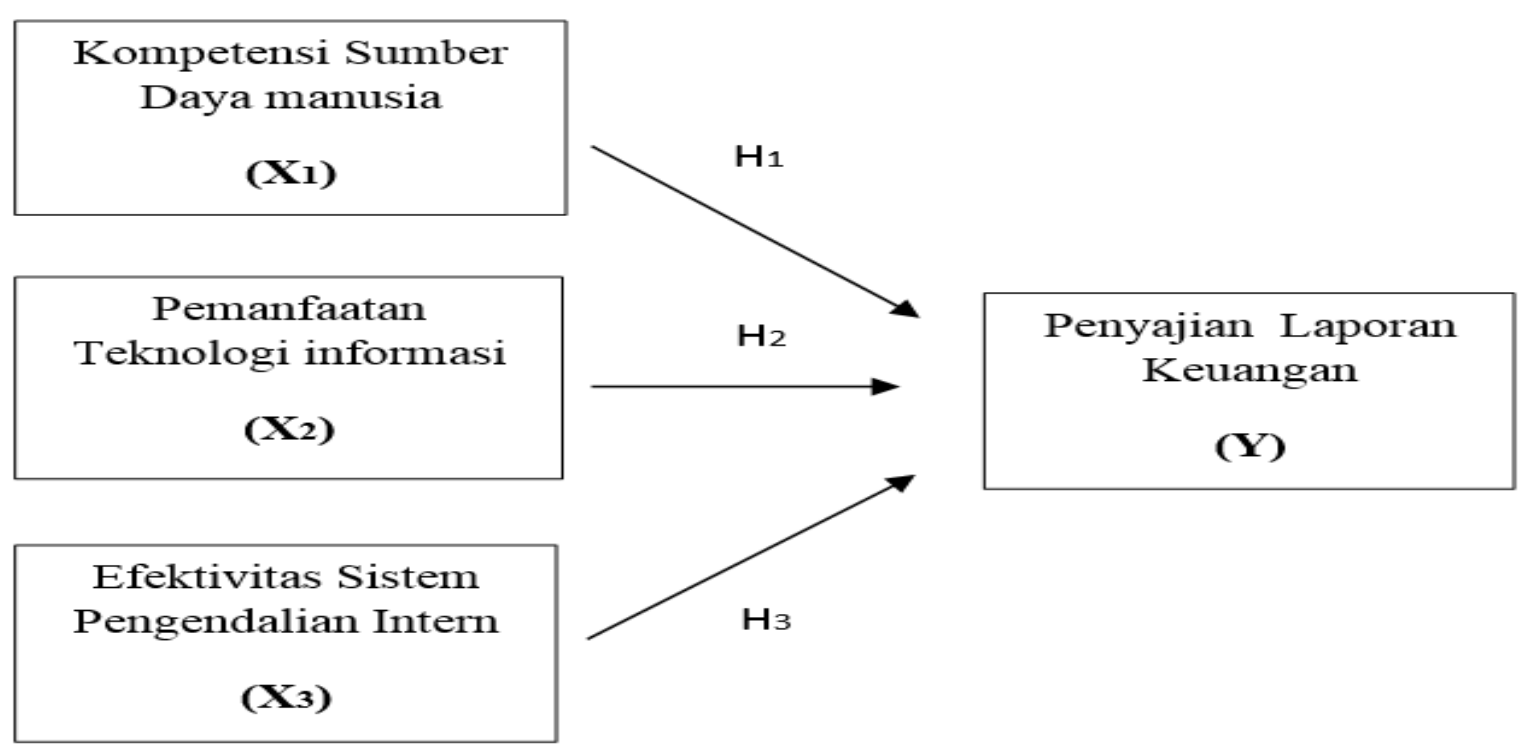

Berdasarkan permasalahan yang telah dikemukakan sebelumnya dan kerangka konseptual tersebut diatas, maka dapat dirumuskan hipotesis sebagai berikut :

\section{Pengaruh kompetensi pegawai terhadap penyajian laporan keuangan rumah sakit TNI AD di KesdamXIV/Hasanuddin.}

Menurut Indriasari dan Nahartyo (2009) kompetensi pegawai adalah kemampuan seseorang atau individu, suatu organisasi (kelembagaan), atau suatu sistem untuk melaksanakan fungsi-fungsi atau kewenangannya untuk mencapai tujuannya secara efektif dan efisien. Kapasitas harus dilihat sebagai kemampuan untuk mencapai kinerja, untuk menghasilkan keluaran-keluaran (outputs) dan hasil-hasil (outcomes). Temuan empiris dari penelitian mereka menunjukkan masih minimnya pegawai berlatar pendidikan akuntansi, belum jelasnya job description, dan belum dilaksanakannya pelatihan-pelatihan untuk menjamin fungsi akuntansi berjalan dengan baik. Walaupun sistem akuntansi yang dibangun sudah baik, tetapi pegawainya tidak memiliki kapasitas untuk melaksanakannya, maka akan menimbulkan hambatan dalam pelaksanaan fungsi akuntansi. Informasi akuntansi sebagai produk dari sistem informasi bisa menjadi tidak valid dan tepat, sehingga informasi yang dihasilkan menjadi informasi yang kurang atau tidak memiliki nilai. Berdasarkan uraian tersebut, maka diduga terdapat hubungan yang positif antara kompetensi pegawai dengan penyajian laporan keuangan rumah sakit TNI AD di Kesdam XIV/Hasanuddin, maka hipotesis yang diajukan:

$\mathrm{H}_{1} \quad$ : Kompetensi pegawai berpengaruh terhadap penyajian laporan keuangan rumah sakit TNI AD di Kesdam XIV/Hasanuddin.

2. Pemanfaatan teknologi informasi terhadap penyajian laporan keuangan rumah sakit TNI AD di Kesdam XIV/Hasanuddin.

Dalam penjelasan peraturan pemerintah No. 56 Tahun 2005 tentang sistem informasi keuangan daerah disebutkan bahwa untuk menindaklanjuti terselenggaranya proses pembangunan yang sejalan 
dengan prinsip tata kelola pemerintahan yang baik (Good Governance), pemerintah pusat dan pemerintah daerah berkewajiban untuk mengembangkan dan memanfaatkan kemajuan teknologi informasi untuk meningkatkan kemampuan mengelola keuangan daerah, dan menyalurkan informasi keuangan daerah kepada pelayanan publik. Pemerintah perlu mengoptimalisasi pemanfaatan kemajuan teknologi informasi untuk membangun jaringan sistem informasi manajemen, dan proses kerja yang memungkinkan pemerintahan bekerja secara terpadu dengan menyederhanakan akses antar unit kerja. Pemanfaatan teknologi informasi tersebut mencakup adanya: (a) pengolahan data, pengolahan informasi, sistem manajemen dan proses kerja secara elektronik dan; (b) pemanfaatan kemajuan teknologi informasi agar pelayanan publik dapat diakses secara mudah dan murah oleh masyarakat diseluruh wilayah negeri ini (Warisno, 2009). Berdasarkan uraian tersebut diduga terdapat hubungan positif antara pemanfaatan teknologi informasi dengan penyajian laporan keuangan rumah sakit TNI AD di Kesdam XIV/Hasanuddin sehingga penulis mengajukan hipotesis:

$\mathrm{H}_{2}$ : Pemanfaatan teknologi informasi berpengaruh terhadap penyajian laporan keuangan rumah sakit TNI AD di Kesdam XIV/Hasanuddin.

\section{Efektivitas sistem pengendalian intern terhadap penyajian laporan keuangan rumah sakit TNI AD di Kesdam XIV/Hasanuddin.}

Menurut PP Nomor 60 Tahun 2008 tentang Sistem Pengendalian Intern Pemerintah (SPIP) pengendalian intern didefenisikan sebagai proses yang integral pada tindakan dan kegiatan yang dilakukan secara terus menerus oleh pimpinan dan seluruh pegawai untuk memberikan keyakinan memadai atas tercapainya tujuan organisasi melalui kegiatan yang efektiv dan efisien, penyajian pelaporan keuangan yang valid dan tepat, pengamanan aset negara, dan ketaatan terhadap peraturan perundang-undangan. Dengan tidak berjalannya pengendalian intern, banyak terjadi penyimpangan dan kebocoran yang ditemukan di dalam laporan keuangan, yang menunjukkan bahwa laporan keuangan tersebut belum memenuhi karakteristik/nilai informasi yaitu valid dan tepat. Masalah-masalah yang ditemukan oleh BPK dalam laporan keuangan pemerintah adalah ketidakpatuhan, ketidakhematan, ketidakefisienan, dan ketidakefektivan serta temuan penyimpangan administrasi akibat dari lemahnya sistem pengendalian intern. Hal ini menunjukkan bahwa laporan keuangan pemerintah belum memenuhi karakteristik/nilai informasi yang disyaratkan, yaitu valid dan tepat. Berdasarkan hasil temuan BPK tersebut, untuk menyajikan laporan keuangan diperlukan perbaikan pengendalian intern agar informasi yang disajikan valid dan tepat. Berdasarkan uraian tersebut, diduga terdapat hubungan positif antara pemanfaatan teknologi informasi dengan penyajian laporan keuangan yang valid dan tepat pada rumah sakit TNI AD di Kesdam XIV/Hasanuddin sehingga diajukan hipotesis:

\section{$\mathrm{H}_{3}$ : Efektivitas pengendalian intern berpengaruh terhadap penyajian laporan keuangan rumah sakit TNI AD di Kesdam XIV/Hasanuddin.}

\section{Metode Penelitian}

Metode penelitian yang digunakan dalam penelitian ini adalah asosiatif. Penelitian ini bertujuan untuk mengetahui pengaruh ataupun hubungan antara variabel kompetensi pegawai, tingkat pemanfaatan teknologi informasi dan efektivitas sintem pengendalian intern terhadap penyajian laporan keuangan di rumah sakit TNI AD di Kesdam XIV/Hasanuddin. Populasi dalam penelitian ini adalah pegawai yang berkaitan langsung dengan bidang keuangan rumah sakit di Kesdam XIV/Hasanuddin. Penentuan sampel dilakukan dengan teknik non probability sampling menggunakan sampling jenuh/sensus. Sampling jenuh/sensus adalah teknik penentuan sampel bila semua anggota populasi digunakan sebagai sampel. Hal ini dilakukan karena jumlah populasi relatif kecil, dan peneliti ingin membuat generalisasi dengan kesalahan yang sangat kecil. Sampling jenuh/sensus digunakan karena informasi yang akan diambil berasal dari sumber yang sengaja dipilih berdasarkan kriteria yang telah ditetapkan peneliti (Sekaran, 2003). 
Menurut Zuliarti (2012) kompetensi pegawai $\left(\mathrm{X}_{1}\right)$ adalah kemampuan dalam tingkatan individu, organisasi/kelembagaan untuk melaksanakan fungsi-fungsi atau kewenangannya untuk mencapai tujuannya secara efektiv dan efisien dengan indikator pendidikan, pengalaman kerja, dan pelatihan yang diukur dengan kuesioner dalam bentuk 10 pertanyaan yaitu : (1) sebagai pegawai dibagian keuangan/akuntansi memiliki kualifikasi dalam bidang keuangan; (2) paling tidak 10 persen dari staf subbagian keuangan/akuntansi merupakan lulusan D3 akuntansi atau lebih tinggi; (3) sebagai bagian keuangan/akuntansi memiliki uraian peran dan fungsi yang jelas; (4) peran dan tanggung jawab seluruh pegawai subbagian keuangan/akuntansi telah ditetapkan secara jelas dalam peraturan daerah; (5) uraian tugas subbagian keuangan/akuntansi telah sesuai dengan fungsi akuntansi yang sesungguhnya; (6) terdapat pedoman mengenai prosedur dan proses akuntansi; (7) subbagian keuangan/akuntansi telah melaksanakan proses akuntansi; (8) subbagian keuangan/akuntansi memiliki sumber daya pendukung operasional yang cukup; (9) pelatihan-pelatihan untuk membantu penguasaan dan pengembangan keahlian dalam tugas dilakukan; (10) dana-dana dianggarkan untuk memperoleh sumber daya, peralatan, dan pelatihan yang dibutuhkan.

Menurut Zuliarti (2012) tingkat pemanfaatan teknologi Informasi $\left(\mathrm{X}_{2}\right)$ adalah tingkat integrasi teknologi informasi pada pelaksanaan tugas-tugas akuntansi dengan indikator komponen sistem informasi, komputerisasi proses akuntansi, dan sistem informasi akuntansi yang diukur dengan kuesioner dalam bentuk 8 pertanyaan yaitu : (1) subbagian akuntansi/keuangan memiliki komputer yang cukup untuk melaksanakan tugas; (2) jaringan internet telah terpasang di unit kerja; (3) jaringan internet telah dimanfaatkan sebagai penghubung antar unit kerja dalam pengiriman data dan informasi yang dibutuhkan; (4) proses akuntansi sejak awal transaksi hingga pembuatan laporan keuangan dilakukan secara komputerisasi; (5) pengolahan data transaksi keuangan menggunakan software yang sesuai dengan peraturan perundang-undangan; (6) laporan akuntansi dan manajerial dihasilkan dari sistem informasi yang terintegrasi; (7) adanya jadwal pemeliharaan peralatan secara teratur; (8) peralatan yang usang/rusak didata dan diperbaiki tepat pada waktunya.

Menurut Zuliarti (2012) efektivitas sistem pengendalian intern $\left(\mathrm{X}_{\mathbf{3}}\right)$ adalah bagian dari pengendalian intern yang meliputi pengorganisasian personel, kebijakan, perencanaan, prosedur, pencatatan, pelaporan, supervisi dan review intern yang diukur dengan kuesioner dalam bentuk 9 pertanyaan yaitu : (1) subbagian keuangan/akuntansi telah menyelenggarakan sistem akuntansi yang meliputi prosedur akuntansi penerimaan kas, prosedur akuntansi pengeluaran kas, prosedur akuntansi aset, dan prosedur akuntansi selain kas; (2) daftar rekening (chart of account) tersedia dan digunakan; (3) transaksi tidak dapat dilakukan tanpa adanya otorisasi dari pihak yang berwenang; (4) setiap transaksi yang terjadi harus didukung dengan bukti transaksi yang valid dan sah; (5) setiap transaksi dicatat dalam buku catatan akuntansi; (6) catatan akuntansi dijaga untuk tetap "up-to-date"; (7) laporan-laporan keuangan direview dan disetujui terlebih dahulu oleh kepala subbagian keuangan/akuntansi sebelum didistribusikan; (8) sistem akuntansi yang ada memungkinkan audit/transaction trail; (9) ada pemisahan tugas dalam rangka pelaksanaan PNBP.

Menurut Zuliarti (2012) penyajian laporan keuangan (Y) adalah penyajian informasi untuk memberikan keyakinan bahwa informasi tersebut valid dan tepat sesuai PP No. 71 Tahun 2010. Variabel diukur dengan kuesioner dalam bentuk 10 pertanyaan yaitu : (1) transaksi serta peristiwa lainnya yang seharusnya disajikan atau yang secara wajar dapat diharapkan untuk disajikan tergambar dengan jujur dalam laporan keuangan; (2) neraca disajikan; (3) laporan realisasi anggaran atau laporan perhitungan PNBP disajikan; (4) catatan atas laporan keuangan disajikan; (5) informasi yang disajikan dalam laporan keuangan dapat diuji; (6) rekonsiliasi dilakukan secara periodik antara catatan akuntansi dengan catatan bank atau catatan pihak eksternal yang membutuhkan konfirmasi atau rekonsiliasi; (7) informasi diarahkan pada kebutuhan umum dan tidak berpihak pada kebutuhan pihak tertentu; (8) informasi yang dibutuhkan segera tersedia ketika diminta; (9) laporan-laporan sering disediakan secara sistematis dan teratur, misal: 
laporan harian, laporan mingguan, laporan bulanan, laporan semester, dan laporan tahunan (bila laporan jarang tersedia berikanlah tanda pada angka satu); (10) Laporan-laporan berikut disampaikan secara sistematis dan teratur yaitu laporan realisasi semester pertama, laporan realisasi anggaran atau laporan perhitungan PNBP, neraca, dan catatan atas laporan keuangan.

Selanjutnya untuk mencapai tujuan penelitian, maka digunakan metode analisis regresi linear berganda. Menurut Zuliarti (2012) regresi linear berganda digunakan untuk meramalkan bagaimana keadaan (naik turunnya) variable dependen (kritarium), bila dua atau lebih variable independen sebagai factor predictor dimanipulasi (dinaik turunkan nilainya).

\section{Hasil Penelitian dan Pembahasan}

Data yang digunakan merupakan data primer yang diperoleh dengan menggunakan kuesioner yang disebarkan kepada responden. Jumlah kuesioner yang disebarkan ke rumah sakit TNI AD di Kesdam XIV/Hasanuddin sebanyak 50 kuesioner. Responden dalam penelitian ini berjumlah 50 responden dari berbagai karakteristik yang dapat dikelompokan berdasarkan umur, jenis kelamin, dan tingkat pendidikan.

Komposisi responden berdasarkan umur yaitu: (1) usia 20-30 tahun dengan jumlah 29 orang (58\%); (2) usia 31-40 tahun dengan jumlah 12 orang (24\%); (3) usia 41-50 tahun terdiri atas 7 orang (14\%); (4) usia 51-60 tahun dengan jumlah 2 orang (4\%).

Komposisi responden berdasarkan jenis kelamin didominasi oleh pria dengan jumlah 40 orang $(80 \%)$ serta wanita dengan jumlah 10 orang orang (20\%).

Komposisi responden berdasarkan latar belakang pendidikan yaitu: (1) lulusan SMU dengan jumlah sebanyak 38 orang (76\%); (2) lulusan S1 dengan jumlah sebanyak 10 orang (20\%); (3) lulusan diploma dengan jumlah 2 orang (4\%). Saat penelitian ini dilakukan, belum ada pegawai yang berlatar belakang pendidikan $\mathrm{S} 2$ atau S3.

Data yang diperoleh kemudian diolah untuk menguji kualitas instrumen penelitian berupa uji validitas dan uji reliabilitas supaya mendapatkan instrumen penelitian yang valid dan reliabel. Pengujian dilakukan dengan bantuan progam SPSS versi 18.

Pengujian validitas dalam penelitian ini menggunakan Pearson Correlation yaitu dengan cara menghitung korelasi antara skor masing-masing butir pertanyaan dengan skor total. Hasil pengujian validitas atas kompetensi pegawai $\left(\mathrm{X}_{1}\right)$, pemanfaatan teknologi informasi $\left(\mathrm{X}_{2}\right)$, efektivitas sistem pengendalian intern $\left(\mathrm{X}_{3}\right)$, dan penyajian laporan keuangan $(\mathrm{Y})$ memiliki kriteria valid dengan nilai signifikansi masing-masing $<0,05$.

Uji reliabilitas dilakukan dengan menguji statistik Cronbach Alpha. Suatu variabel dikatakan reliabel jika memberikan nilai Cronbach Alpha $>0,60$. Hasil uji reliabilitas untuk variabel dependen dan indipenden yang didapat peneliti berdasarkan output SPSS adalah nilai Cronbach Alpha 0,966 > 0,60 sehingga dapat dikatakan bahwa variabel-variabel tersebut reliabel.

Uji normalitas dilakukan untuk menguji apakah dalam model regresi, variabel dependen dan variabel independen keduanya mempunyai distribusi normal. Persyaratan data tersebut normal jika probabilitas atau p > 0,05 pada uji normalitas dengan Kolmogorov-Smirnov $(K-S)$. Hasil uji normalitas dinyatakan memenuhi persyaratan distribusi normal.

Uji multikolinearitas adalah uji yang dilakukan untuk memastikan apakah di dalam sebuah model regresi ada interkorelasi atau kolinearitas antar variabel bebas. Interkorelasi adalah hubungan yang linear atau hubungan yang kuat antara satu variabel bebas atau variabel prediktor dengan variabel prediktor lainnya di dalam sebuah model regresi. Interkorelasi itu dapat dilihat dengan nilai koefisien korelasi antara variabel bebas dan nilai variance inflation factors (VIF) serta tolerance. Jika nilai tolerance $>0,1$ dan VIF $<10$, maka dinyatakan tidak ada korelasi sempurna antar variabel independen. Hasil uji multikolinearitas seluruh angka VIF berada di bawah 10,00 dan nilai tolerance lebih dari 0,01 menunjukkan bahwa pada model regresi tidak ada masalah multikolinearitas dan regresi diasumsikan layak. 
Uji heteroskedastisitas pada penelitian ini dilakukan dengan menggunakan grafik scatterplot dan melalui uji glesjer. Penilaian melalui grafik scatterplot dilakukan dengan melihat pola yang terbentuk pada grafik plot antara nilai prediksi variabel terikat dengan residual. Apabila membentuk suatu pola titik yang bergelombang atau melebar kemudian menyempit maka disimpulkan telah terjadi heteroskedastisitas, namun jika tidak ada pola yang jelas serta titik-titik menyebar di atas dan di bawah angka 0 pada sumbu $\mathrm{Y}$ maka tidak terjadi heteroskedastisitas. Melalui uji glesjer akan dilihat probabilitas signifikansi masingmasing variabel independen, apabila lebih besar dari 0,05 maka disimpulkan tidak terjadi heteroskedastisitas dalam model regresi. Hasil uji scatterplot tidak ada pola tertentu karena titik meyebar tidak beraturan di atas dan di bawah sumbu 0 pada sumbu Y. Maka dapat disimpulkan tidak terdapat gejala heteroskedastisitas dan model regresi dinyatakan layak.

Uji Autokorelasi adalah sebuah analisis statistik yang dilakukan untuk mengetahui adakah korelasi variabel yang ada di dalam model prediksi dengan perubahan waktu. Uji Durbin Watson akan menghasilkan nilai Durbin Watson (DW) yang nantinya akan dibandingkan dengan dua (2) nilai Durbin Watson Tabel, yaitu Durbin Upper (DU) dan Durbin Lower (DL). Dikatakan tidak terdapat autokorelasi jika nilai DW > DU dan (4-DW) > DU atau bisa dinotasikan juga sebagai berikut: (4-DW) > DU < DW. Hasil uji autokorelasi menggunakan uji Durbin Watson dengan kriteria $\mathrm{k}=3$ dan $\mathrm{df}=50$, diperoleh angka DL sebesar 1,4206 dan DU sebesar 1,6739. Nilai DW lebih besar dari nilai DU (1,681 > 1,673), sehingga dinyatakan bahwa tidak terdapat autokorelasi pada model regresi ini.

Koefisien korelasi digunakan untuk mengetahui hubungan antara variabel independen kompetensi pegawai $\left(\mathrm{X}_{1}\right)$, tingkat pemanfaatan teknologi informasi $\left(\mathrm{X}_{2}\right)$, dan efektivitas sistem pengendalian intern $\left(\mathrm{X}_{3}\right)$ terhadap variabel dependen penyajian laporan keuangan $(\mathrm{Y})$ secara serentak. Nilai koefisien korelasi berkisar antara 0 sampai 1. Jika nilai semakin mendekati 1 maka hubungan yang terjadi semakin kuat, sebaliknya jika mendekati 0 berarti semakin lemah. Hasil uji korelasi antar variabel menunjukkan terjadi korelasi yang kuat antar variabel baik variabel independen maupun dependen. Hal ini ditunjukkan dengan semua nilai koefisien korelasi yang berada di atas $60 \%$ atau $(0,60)$ dan mendekati nilai 1,00 .

\section{Tabel 1. Hasil Regresi Berganda}

\section{Coefficients $^{\mathrm{a}}$}

\begin{tabular}{|c|c|c|c|c|c|c|c|c|c|}
\hline \multirow{2}{*}{\multicolumn{2}{|c|}{ Model }} & \multicolumn{2}{|c|}{$\begin{array}{c}\text { Unstandardized } \\
\text { Coefficients }\end{array}$} & \multirow{2}{*}{$\begin{array}{c}\text { Standardized } \\
\text { Coefficients } \\
\text { Beta }\end{array}$} & \multirow[t]{2}{*}{$\mathbf{t}$} & \multirow[t]{2}{*}{ Sig. } & \multicolumn{3}{|c|}{ Correlations } \\
\hline & & $\mathbf{B}$ & Std. Error & & & & $\begin{array}{l}\text { Zero- } \\
\text { order }\end{array}$ & Partial & Part \\
\hline \multirow{4}{*}{1} & $\begin{array}{l}\text { (Consta } \\
\text { nt) }\end{array}$ & 4,196 & 3,225 & & 1,301 &, 200 & & & \\
\hline & $\mathbf{x} 1$ &, 092 &, 107 & ,095 &, 864 &, 392 &, 689 &, 126 &, 061 \\
\hline & $\times 2$ &, 406 &, 175 &, 336 & 2,326 &, 024 &, 824 &, 324 &, 165 \\
\hline & $\times 3$ &, 536 &, 134 &, 504 & 4,004 &, 000 &, 845 &, 508 &, 284 \\
\hline
\end{tabular}

Sumber : Hasil Olahan Data (2018)

Uji-t digunakan untuk mengetahui apakah dalam model regresi variabel independen kompetensi pegawai $\left(\mathrm{X}_{1}\right)$, tingkat pemanfaatan teknologi informasi $\left(\mathrm{X}_{2}\right)$ dan efektivitas pengendalian intern $\left(\mathrm{X}_{3}\right)$ secara parsial berpengaruh signifikan terhadap variable dependen penyajian laporan keuangan (Y). Dalam uji parsial ini, kriteria pengambilan keputusan uji-t dengan tingkat signifikan 5\% $(0,05)$. Ho diterima bila thitung < ttabel atau Sig. < 0,05, dan Ho ditolak bila thitung < ttabel atau Sig. > 0,05. Nilai sig. variabel kompetensi pegawai $\left(\mathrm{X}_{1}\right)$ adalah sebesar 0,392 , dan ini artinya Ho ditolak dan dengan kata lain tidak 
terdapat pengaruh signifikan secara parsial antara kompetensi pegawai $\left(\mathrm{X}_{1}\right)$ terhadap penyajian laporan keuangan (Y). Nilai sig. variabel tingkat pemanfaatan teknologi informasi $\left(\mathrm{X}_{2}\right)$ dan efektivitas sistem pengendalian intern $\left(\mathrm{X}_{3}\right)$ ialah sebesar 0,024 dan 0,000 untuk masing-masing variabel. Nilai sig. dari kedua variabel ini berada dibawah angka 0,05 yang berarti Ho diterima dan dengan kata lain, terdapat pengaruh signifikan secara parsial, antara pemanfaaan teknologi informasi $\left(\mathrm{X}_{2}\right)$ terhadap penyajian laporan keuangan $(\mathrm{Y})$, dan efektivitas sistem pengendalian intern $\left(\mathrm{X}_{3}\right)$ terhadap penyajian laporan keuangan $(\mathrm{Y})$.

Koefisien determinasi $\left(\mathrm{R}^{2}\right)$ sebesar 0,768 yang memiliki arti bahwa variabel dependen penyajian laporan keuangan (Y) dipengaruhi atau dideterminasi sebesar 76,8\% oleh ketiga variabel kompetensi pegawai $\left(\mathrm{X}_{1}\right)$, pemanfaatan teknologi informasi $\left(\mathrm{X}_{2}\right)$ dan efektivitas pengendalian intern $\left(\mathrm{X}_{3}\right)$ secara bersamaan, sedangkan $23,2 \%$ lainnya dipengaruhi atau dideterminasi oleh variabel-variabel yang tidak diteliti dalam penelitian ini.

\section{Pengaruh Kompetensi Pegawai Terhadap Penyajian Laporan Keuangan}

Hasil dalam penelitian ini, nilai sig. variabel kompetensi pegawai $\left(\mathrm{X}_{1}\right)$ ialah sebesar 0,392 dan ini artinya Ho ditolak dan dengan kata lain tidak terdapat pengaruh signifikan secara parsial antara kompetensi pegawai $\left(\mathrm{X}_{1}\right)$ terhadap penyajian laporan keuangan $(\mathrm{Y})$. Temuan ini sejalan dengan studi sebelumnya oleh Sukmaningrum (2012), dalam studinya juga menyatakan bahwa kompetensi pegawai bukan satu-satunya faktor yang terpenting dalam menentukan penurunan penyajian sebuah laporan keuangan. Ada faktor penting lain yang ikut menentukan penyajian laporan keuangan. Dari penelitian di rumah sakit TNI AD di Kesdam XIII/Hsn ditemukan data demografi responden/pegawai yang menempati posisi pengelola keuangan masih tergolong baru menapaki karir dan responden yang berlatar belakang pendidikan diploma atau S-1 hanya sebesar 20-24\%, selain itu proses penyusunan laporan keuangan telah didukung dengan teknologi informasi. Hal ini menyebabkan semua proses pelaporan keuangan sudah terlaksana secara otomatis dengan tingkat akurasi yang tinggi, sehingga pengelola keuangan di rumah sakit TNI AD di Kesdam XIV/Hasanuddin yang bertugas membuat laporan keuangan tidak harus mempunyai pengetahuan yang memadai tentang siklus akuntansi karena proses akuntansi seluruhnya telah dikerjakan oleh sistem yang ada. Pegawai dalam hal ini hanya menginput data saja. Dalam hal ini, dapat diartikan bahwa peran pegawai dalam pelaksanaan pencatatan dan pelaporan keuangan sudah tidak terlalu krusial karena telah tergantikan oleh sistem. Sekalipun pegawai keuangan tidak terlalu memahami dengan baik siklus akuntansi, penyajian laporan keuangan tidak akan terganggu validitas dan ketepatannya.

\section{Pengaruh Pemanfaatan Teknologi Indoneasi Terhadap Penyajian Laporan Keuangan}

Hasil dalam penelitian ini, nilai sig. variabel tingkat pemanfaatan teknologi informasi $\left(\mathrm{X}_{2}\right)$ ialah sebesar 0,024 yang berarti Ho diterima dan dengan kata lain terdapat pengaruh signifikan secara parsial, antara pemanfaaan teknologi informasi $\left(\mathrm{X}_{2}\right)$ terhadap penyajian laporan keuangan $(\mathrm{Y})$. Penelitian dengan hasil serupa oleh Zuliarti (2012) menekankan bahwa optimalisasi pemanfaatan kemajuan teknologi informasi untuk membangun jaringan sistem informasi manajemen dan proses kerja yang memungkinkan pemerintahan bekerja secara terpadu dengan menyederhanakan akses antar unit kerja dalam menyajikan informasi laporan keuangan yang valid dan tepat. Hal ini sejalan dengan hasil penelitian Pandey (2014) yang menyatakan bahwa pemanfaatan teknologi informasi berpengaruh positif dan signifikan terhadap penyajian laporan keuangan dan ketepatwaktuan pelaporan keuangan rumah sakit. Penerapan standar akuntansi pemerintah berbasis akrual pada rumah sakit tentunya membutuhkan perangkat teknologi informasi untuk memproses transaksi keuangan yang semakin kompleks. Hal ini berarti bahwa pemanfaatan teknologi informasi dengan penggunaan komputer dan jaringan internet dalam penyelenggaraan sistem akuntansi dan pelaporan keuangan rumah sakit berpengaruh secara signifikan terhadap penyajian laporan keuangan rumah sakit yang valid dan tepat. 


\section{Pengaruh Efektivitas Sistem Pengendalian Intern Terhadap Penyajian Laporan Keuangan}

Hasil dalam penelitian ini, nilai sig. variabel efektivitas sistem pengendalian intern $\left(\mathrm{X}_{3}\right)$ ialah sebesar 0,000 yang berarti Ho diterima dan dengan kata lain terdapat pengaruh signifikan secara parsial antara efektivitas sistem pengendalian intern $\left(\mathrm{X}_{3}\right)$ terhadap penyajian laporan keuangan $(\mathrm{Y})$. Hasil penelitian ini sejalan dengan Zuliarti (2012) yang menunjukkan bahwa sistem pengendalian intern memiliki peranan besar dalam melakukan pengendalian entitas-entitas penyelenggara tugas dan fungsi rumah sakit, dalam hal ini pihak pegawai dan teknologi yang mendukung, terutama dalam hubungannya dengan penyajian laporan keuangan. Pandey (2014) menyatakan bahwa sistem pengendalian intern yang memadai dapat berperan dalam memaksimalkan kompetensi pegawai dan berhubungan erat dengan penyajian laporan keuangan. Peran krusial tersebut merupakan kontrol atas kinerja pegawai. Giat pengawasan dan pengendalian pada aspek pegawai sebagai pihak yang menjalankan pekerjaan (pihak yang mengendalikan). Sistem pengendalian intern yang solid bisa memastikan pegawai dan sistem komputer dalam menjalankan pekerjaan akuntansinya sesuai standar, sehingga instansi terhindar dari fraud, tindakan korupsi, dan berbagai bentuk tindakan kecurangan.

\section{Kesimpulan dan Saran}

Penelitian ini bertujuan untuk mengetahui pengaruh kompetensi pegawai, tingkat pemanfaatan teknologi informasi, dan efektivitas pengendalian intern terhadap penyajian laporan keuangan rumah sakit TNI AD di kesdam XIV/Hasanuddin. Berdasarkan hasil penelitian maka dapat diambil kesimpulan sebagai berikut ;

1. Kompetensi pegawai tidak berpengaruh signfikan terhadap penyajian laporan keuangan rumah sakit TNI AD di Kesdam XIV/Hasanuddin. Hal ini disebabkan oleh; (1) dari data demografi responden, didapati pegawai yang menempati posisi pengelola keuangan masih tergolong baru menapaki karir dan responden yang berlatar belakang pendidikan diploma atau S-1 hanya sebesar 20-24\%; (2) proses penyusunan laporan keuangan telah didukung dengan teknologi informasi.

2. Pemanfaatan teknologi informasi berpengaruh signfikan terhadap penyajian laporan keuangan di rumah sakit TNI AD di Kesdam XIV/Hasanuddin, sehingga semakin optimal pemanfaatan teknologi informasi maka semakin baik penyajian laporan keuangan.

3. Efektivitas sistem pengendalian intern berpengaruh signfikan terhadap penyajian laporan keuangan rumah sakit TNI AD di Kesdam XIV/Hasanuddin, sehingga semakin efektif sistem pengendalian intern maka semakin baik penyajian laporan keuangan.

Berdasarkan hasil penelitian yang dilakukan adapun saran-saran yang dapat diberikan sebagai berikut:

1. Penelitian selanjutnya dapat menambah variabel independen lain yang belum diteliti pada penelitian ini agar dapat mengetahui faktor-faktor lain yang mungkin mempengaruhi penyajian laporan keuangan rumah sakit.

2. Penelitian selanjutnya dapat mempertimbangkan menggunakan metode-metode campuran kuantitatif dan kualitatif dalam penelitian, dimana metode kualitatif digunakan untuk menjelaskan hasil yang diperoleh dari metode kuantitatif sehingga dapat memperoleh kesimpulan yang sesuai dengan kondisi sebenarnya. 


\section{Daftar Pustaka}

Indriasari, E., Nahartyo. 2009. Pengaruh Kapasitas SDM, Pemanfaatan Teknologi Informasi dan Pengendalian Intern Akuntansi Terhadap Keterandalan dan Ketepatwaktuan Pelaporan Keuangan Pemerintah Daerah, Studi pada Pemerintah kota Palembang dan Kabupaten Ogan Ilir. Jurnal Akuntansi.

Nuryanto M., N.N. Afiah. 2013. The Impact of Apparatus Competence, Information Technology Utilization and Internal Control on Financial Statement Quality (Study on Local Government of Jakarta Province - Indonesia). World Review of Business Research. (Vol. 3) : N0. 4 November 2013 Issue. pp 157-17.

Pandey, B.A.R. 2014. Pengaruh Kualitas Sumber Daya Manusia, Sarana Pendukung, dan Komitmen Pimpinan Terhadap Kinerja Satuan Kerja Perangkat Daerah (SKPD) Dalam Penyususnan Laporan Keuangan SKPD Di Lingkungan Pemerintah Provinsi Sulawesi Utara. Tesis. Universitas Sam Ratulangi. Manado.

Peraturan Direktur Jenderal Perencanaan Pertahanan Kementrian Pertahanan Nomor 13 Tahun 2011 tentang Pedoman Pelaksanaan Pola Pengelolaan Keuangan Penerimaan Negara Bukan Pajak Pelayanan Masyarakat Umum Rumah Sakit di Lingkungan Kementrian Pertahanan dan Tentara Nasional Indonesia.

Peraturan Direktur Jenderal Perencanaan Pertahanan Kementrian Pertahanan Nomor 18 Tahun 2014 atas Perubahan Peraturan Direktur Jenderal Perencanaan Pertahanan Kementrian Pertahanan Nomor 13 Tahun 2011 tentang Pedoman Pelaksanaan Pola Pengelolaan Keuangan Penerimaan Negara Bukan Pajak Pelayanan Masyarakat Umum Rumah Sakit di Lingkungan Kementrian Pertahanan dan Tentara Nasional Indonesia.

Peraturan Kepala Staf Angkatan Darat Nomor Perkasad / 24 / IX / 2012 tentang Pola Pengelolaan Keuangan Penerimaan Negara Bukan Pajak Pelayanan Masyarakat Umum Rumah Sakit Di Lingkungan Tentara Nasioanal Indonesia Angkatan Darat.

Peraturan Kepala Staf Angkatan Darat Nomor Perkasad / 723 / IX / 2016 tentang Pola Pengelolaan Keuangan Penerimaan Negara Bukan Pajak Pelayanan Masyarakat Umum Rumah Sakit Di Lingkungan Tentara Nasioanal Indonesia Angkatan Darat.

Peraturan Menteri Pertahanan Republik Indonesia Nomor 30 Tahun 2008 tentang Pedoman Pengelolaan Keuangan Penerimaan Negara Bukan Pajak di Lingkungan Depatermen Pertahanan dan Tentara Nasional Indonesia.

Peraturan Menteri Pertahanan Republik Indonesia Nomor 51 Tahun 2014 atas Perubahan Peraturan Menteri Pertahanan Republik Indonesia Nomor 30 Tahun 2008 tentang Pedoman Pengelolaan Keuangan Penerimaan Negara Bukan Pajak di Lingkungan Depatermen Pertahanan dan Tentara Nasional Indonesia.

Peraturan Pemerintah Republik Indonesia Nomor 56 Tahun 2005 tentang Sistem Informasi Keuangan Daerah.

Peraturan Pemerintah Republik Indonesia No 71 Tahun 2010 tentang Standar Akuntansi Pemerintahan.

Undang-Undang Nomor 17 Tahun 2003 tentang Keuangan Negara.

Undang-Undang Nomor 1 Tahun 2004 tentang Perbendaharaan Negara.

Undang-Undang Nomor 15 Tahun 2004 tentang Pemeriksaan Pengelolaan dan Tanggung Jawab Keuangan Negara.

Sekaran, U. 2003. Research Methods For Business, A Skill-Building Approach. John Wiley and Sons Inc, New York. 
Sukirman, H., Sularso, dan E.S. Nugraheni. 2012. Faktor-Faktor Yang Mempengaruhi Keterandalan dan Ketepatwaktuan Pelaporan Keuangan Dengan pengendalian Intern Akuntansi Sebagai Variabel Pemoderasi (Studi Empiris Pada Pemerintah Daerah Kabupaten Banyumas). Jurnal.

Sukmaningrum, T. 2012. Analisis Faktor-Faktor Yang Mempengaruhi Kualitas Informasi Laporan Keuangan Pemerintah Daerah.

Van Beest, et. Al. 2009. Quality of Financial Reporting, Measuring Qualitative Characteristic. Nijmegen Center for Economics (NiCE).

Andi. Wahana Komputer. 2003. Panduan Aplikatif Sistem Akuntansi Online Berbasis Komputer.

Warisno. 2009. Faktor-faktor Yang Mempengaruhi Kinerja Satuan Kerja Perangkat Daerah (SKPD) Di Lingkungan Pemerintah Provinsi Jambi. Tesis. Universitas Sumatera Utara. Medan.

Warongan, J.D.L., G. Pagalung, P. Uppun and A. H. Habbe. 2014. The Effect of Effectiveness Mediation of Internal Control System on Competency of Human Resources and Audit Opinion in Previous Year towards Quality of Financial Statement. Journal of Research in Business and Management, Vol. 2. Issue 11. pp 9-16. ISSN 2347-3002.

Zuliarti. 2012. Pengarauh Kapasitas Sumber Daya Manusia, Pemanfaatan Teknologi Informasi, dan Pengendalian Intern Akuntansi Terhadap Nilai Informasi Pelaporan Keuangan Pemerintah Daerah. Studi Pada Pemerintah Kabupaten Kudus. Skripsi. Universitas Muria Kudus. 